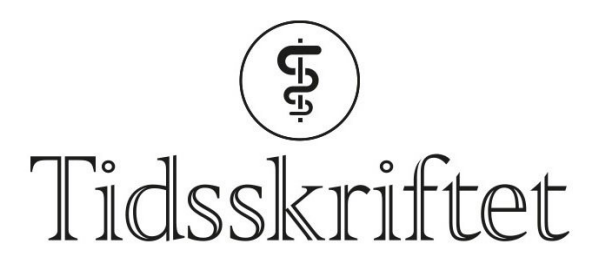

DEN NORSKE LEGEFORENING

\title{
Fluorescerende farge påviser levende tuberkulosebakterier
}

FRA ANDRE TIDSSKRIFTER

RUTH HALSNE

Tidsskriftet

En fluorescerende fargesubstans som tas opp av mykobakterier, kan påvise levende tuberkulosebakterier og brukes til å følge pasienten under behandling.

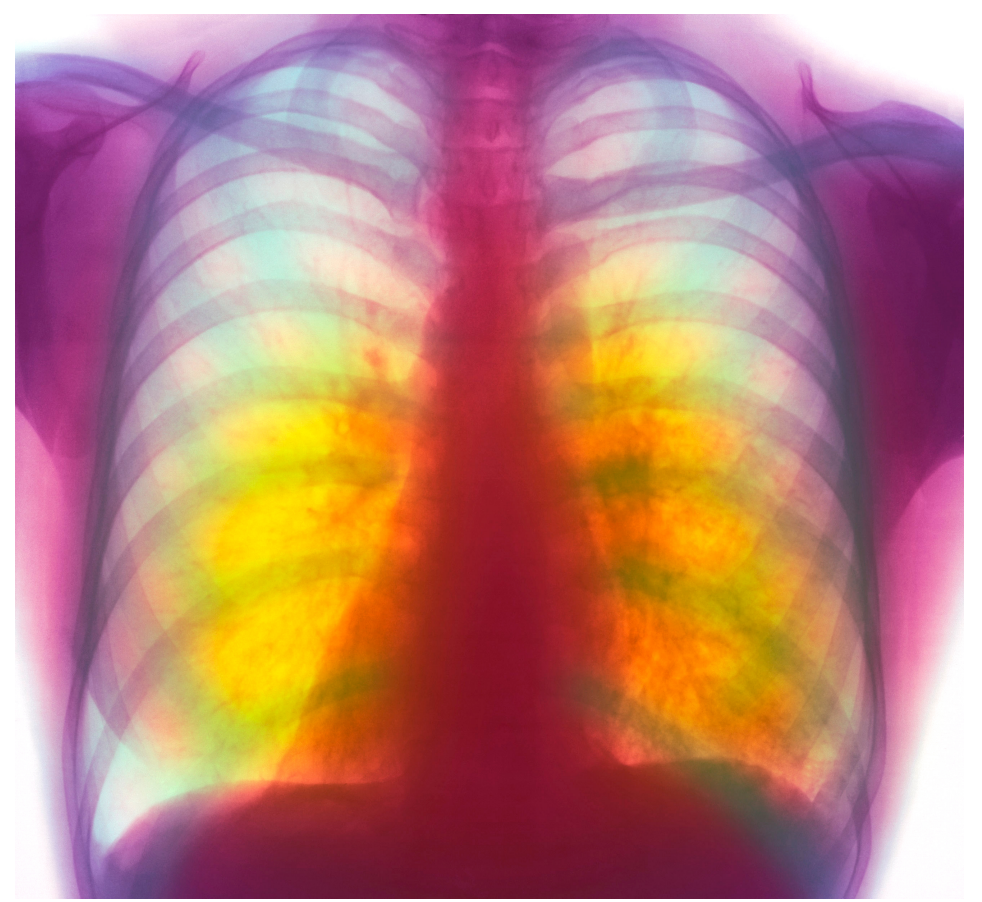

Illustrasjonsfoto: Science Photo Library/NTB Scanpix

Tuberkulose er en alvorlig infeksjonssykdom forårsaket av Mycobacterium tuberculosis, som viser $\emptyset$ kende resistens mot behandling. Nåværende mikroskopibaserte metoder for tuberkulosediagnostikk er arbeidskrevende, kan være uspesifikke og påviser både levende og døde mykobakterier.

Det er nå utviklet en ny metode der man bruker en fluorescerende probe som kan påvise aktive tuberkulosebakterier og dermed skille mellom levende og døde tuberkulosebakterier (1). Proben kalles DMN-Tre og består av 4-N,N-dimethylamino-1,8naphthalimide (4-DMN), som er en fluorescerende fargesubstans, og trehalose, som ved tilsetting tas aktivt opp i mykobakterier i løpet av zo minutter. Når dette trehalosekonjugatet metaboliseres av mykobakteriene, vil fargesubstansen avgi 700 ganger 
mer fluorescens i bakteriemembranens hydrofobe lipidlag sammenlignet med signal i vannløselig miljø utenfor membranen.

Fargingen er spesifikk for mykobakterier og bakterier i actinobacteriafylum. Døde mykobakterier mangler aktiv metabolisme og vil ikke gi falskt positive svar, selv uten vasking. Omdanningen av trehalose utføres av et acyltransferaseproteinkompleks kalt Antigen 85, som bare finnes hos medlemmer av orden Actinomycetales i Actinobacteria.

- Dette er et godt eksempel på hvordan man kan oppnå økt sensitivitet ved mikroskopisk påvisning av tuberkulosebakterier på under en time, sier Tone Tønjum, som er professor ved Avdeling for mikrobiologi, Universitetet i Oslo. Testen er enkel i bruk og kan benyttes i feltet for diagnostikk av tuberkulose direkte i spyttprøver og andre kliniske materialer. Testen kan også brukes til å følge pasienten over tid og undersøke om behandlingen fungerer optimalt, sier Tønjum.

LITTERATUR:

1. Kamariza M, Shieh P, Ealand CS et al. Rapid detection of Mycobacterium tuberculosis in sputum with a solvatochromic trehalose probe. Sci Transl Med 2018; 10:1 - 12. [PubMed][CrossRef]

Publisert:3. september 2018. Tidsskr Nor Legeforen. DOI: 10.4045/tidsskr.18.0454

(C) Tidsskrift for Den norske legeforening 2020. Lastet ned fra tidsskriftet.no 